Prianischnikov, who started a series of comprehensive seedling analyses in Schulze's laboratory in 1892, and continued them on his return to Moscow, put forward the suggestion, based on reasonable but indirect evidence, that the essential intermediate in this secondary process was ammonia. Schulze, who had himself adumbrated the same idea in 1888, but had been unwilling to adopt it for lack of direct chemical evidence, was unconvinced, and was to remain so until Prianischnikov and his pupils produced, in the years between 1905 and 1912, what was probably valid, though still indirect, evidence that some oxidative mechanism was concerned. In his account of the development of the subject during the twenty years $1892-1912$ the reviewer is of the opinion that Prianischnikov has perhaps been just a little ungracious to his old teacher. In his earlier years Schulze had been strongly influenced by the work and philosophical approach of the first great master in protein chemistry, Ritthausen, whose book "Die Eiweisskörper der Getreidarten, Hulsenfrüchte und Ölsamen", published in 1872, he regarded as a landmark. He was convinced that the interpretation of plant metabolism must be based on sound chemical observation and was thus led to spend most of his life combating what was to him the evil influence of the speculation that was rife at that period in the literature of plant physiology.

Prianischnikov, as a younger man, must have found Schulze's views dull and rather unimaginative, just as the casual reader of Schulze's numerous papers would do to-day. In the event his interpretation of the role of ammonia in asparagine production has been shown to be correct; but some of the evidence that he advances in support of it in his book (pp. $18,19)$ is culled from Schulze's earlier work, and this is not brought out quite as clearly as it might have been. 'The controversy, of course, is of no more than historical interest to-day but it should never be forgotten, for these early views on the role of ammonia in amino-acid metabolism antedated by several years the more definitive work of Knoop on oxidative deamination in the animal organism. Such criticism, nevertheless, need not lessen our appreciation of Prianischnikov's own contribution, and his thesis that ammonia was the alpha and omega of protein synthesis and degradation in plants undoubtedly helped to clarify what was then a rather confused field of study. In this the influence of Boussingault, who had put forward a similar suggestion about urea in animal protein metabolism, is apparent.

In 1912 Prianischnikov abandoned work in the metabolism of organic nitrogenous compounds and was to devote the rest of his long life to investigations on ammonia and nitrate nutrition in plants, which he realized might yicld results of much greater economic importance, especially to a country where agriculture was as backward as it was until recently in Russia. Much of the work that was carried out under his guidance at the T'imiriazev College has been inaccessible to those who are unable to read Russian, though the outlines of it have been known to us through the summaries that he published from time to time in German journals. In the last four chapters of his book the whole subject is now treated on a historical basis and his own work is presented in expanded form. Once again we can be grateful for a long memory and his penetrating assessment of the value of much of the early literature. His own researches will have a lasting effect on agronomic practice and show that he belonged to the ranks of the world's great scientists. There can be no doubt that the contributions which he made to the economic development of his country were profound, and that the honours which came to him in his later years were well deserved.

It is an illuminating reflexion of conditions in the publishing world to-day that the English translation of this unique book should be produced in typewritten form instead of normal print. This complaint never. theless does not lessen our gratitude to Prof. Wilde and his colleagues for having made the translation available to us.

A. C. Chibnall

\section{PHYSICS OF THE IONOSPHERE}

\section{Die lonosphäre}

Ihre Bedeutung für Geophysik und Radioverkehr. Von Dr. Karl Rawer. Pp. $189+10$ plates. (Groningen: P. Noordhoff N.V., 1952.) Paper, 12.50 florins $(28 s .6 d$.$) ; or cloth, 14.50$ florins $(32 s .6 d$.$) .$

T HE practical importance of the ionosphere rests on the use which the radio engineer must, perforce, make of it if he is to maintain a modern world-wide communication network. Although the continually changing characteristics of the different layers may be a constant source of anxiety to the engineer, familiarity with similar changes in the past and the use of empirical methods allow him to extrapolate current behaviour into the future with sufficient accuracy for his needs without having to study the underlying physics.

On the other hand, the changes whi $h$ harass the engineer are grist to the mill of the physicist whose aim is to explain the behaviour of the ionosphere in terms of an atmosphere irradiated by solar ionizing radiation in the presence of the earth's magnetic field.

Books on the ionosphere are rare, probably because the number of potential readers is limited even when both physicists and engineers are included. Small though this number may be, a treatment of the subject, if it is to be successful, must be written either for the physicist or the engineer since their interests and points of view are essentially different. Dr. K. Rawer's monograph is intended primarily for the physicist who wishes to make a rapid survey of ionospheric physies and of the important problems of finding the upper and lower limiting frequencies for the propagation of radio waves through the ionosphere at oblique incidence. In a book of this size, detailed discussion of the wide range of subjects covered is not possible; but space has been found, in most cases, not only for a brief review of the background but also for an indication of more recent developments.

Dr. Rawer would, no doubt, agree with Samuel Johnson's remark that "a man will turn over half a library to make one book". Nevertheless, he has not been indiscriminate in quoting references, particularly to earlier investigations, merely for the sake of completeness ; about half of the two hundred and fifty sources quoted refer to work published during the past eight years, and the inquisitive reader who wishes to examine in more detail a particular problem which interests him will find ample guidance for further study. The quality of the typography and make-up of the volume conform to the high standard expected in books published in the Netherlands.

C. M. MrNnis 